\title{
Exploring New Mechanism of Combined Training Talents Based on "Double Cultivation" Plan
}

\author{
Jiali Luo \\ Dean's Office \\ Beijing Institute of Fashion Technology \\ Beijing, China \\ Jie Zheng \\ Enrollment and Employment Service \\ Beijing Institute of Fashion Technology \\ Beijing, China \\ Yang Xi \\ Dean's Office \\ Beijing Institute of Fashion Technology \\ Beijing, China
}

\author{
Xiaohui Li \\ Dean's Office \\ Beijing Institute of Fashion Technology \\ Beijing, China \\ Hongna Zhang \\ Students' Affairs Division \\ Beijing Institute of Fashion Technology \\ Beijing, China \\ Ying Zhang \\ Dean's Office \\ Beijing Institute of Fashion Technology \\ Beijing, China
}

\begin{abstract}
The school relies on the Beijing "double training plan" project, and actively explore the mechanism of the high level talents with the Central Universities. A detailed system and the implementation of the program have been developed in the selection of students, training programs, teaching operation management and management and feedback. There is a good effect about professional construction, faculty construction, the construction of the style of study and so on in the school.
\end{abstract}

Keywords-dual culture; combined training; training scheme; virtual teaching and research section

\section{INTRODUCTION}

Higher education is in a critical period of comprehensive deepening reform, carrying the historical task of providing high-end talent intelligence support for the whole society. Beijing as a national political center, cultural center, international exchange center, science and technology innovation center, for further innovation, the high level of talent training mechanism, to effectively meet the demand for college students to the high quality education resources, comprehensively improve the level of running a college, the Beijing Municipal Education Commission make full use of condition, that the center of Beijing city belongs to the line-up and is rich in high quality education resources, and began to actively promote the implementation by the Beijing Municipal Colleges and universities in Beijing and the Central University joint training outstanding students "double training plan" since 2014.

\section{IMPLEMENTATION Mode OF "DOUble Training Plan"} "Double training plan" adhering to principle of the

Funded projects: Teacher education development center(Beijing municipal)

Grant No.RCQJ02160202 "comprehensive reform, innovating mechanism, crossing integration, sharing resource ", strengthen macro planning and top-level design to break the barriers between the colleges and universities in Beijing, make the formation of the advantages of disciplines resources in terms of personnel training efforts to achieve the sharing of college education resources and social resources, establish cross fostering long-term cooperation a new mechanism for the development of all-round, wideranging and multi-level of high level talents. Implementation of the "double training plan" mainly adopts three ways: the first is by the Beijing municipal colleges and universities every year the selection of a number of outstanding students in Central University in Beijing to visit the school, in accordance with the " $3+1 "$ and "1+2+1" training mode, which is the first 3 year in the Central University, fourth year in the Beijing municipal colleges and universities or is the first and fourth year in the Beijing municipal colleges and universities, second and third year in the Central University; the second is the delivery of outstanding students for a period of 1 years of short-term visiting from Beijing municipal colleges and universities to Central University which set up Beijing central social needs of the professional, namely first, second and fourth year in Beijing municipal colleges and universities, third year in Central University; the third is to encourage outstanding students in Beijing municipal colleges and universities to study in Central University offering summer school courses quality courses.

\section{RELYING ON THE "DOUBle TRAINING PROGRAM" TO ESTABLISH A JOINT TRAINING OF PERSONNEL WORK OBJECTIVES}

Garment industry is fashion industry of the most mature fashion guide ability and the most extensive influence. As the 
domestic garment industry's first class universities, school make full use of our own advantages, has a unique condition in strengthening the talent training in the fashion industry. According to spirit of the "double training plan" and Beijing's urban location, in-depth studies of school advantageous time to development of the fashion industry in the middle class in our country increasingly large changes in social structure, combined with our school running characteristics, accelerate the construction of our school has not yet been established in fashion design, information visualization design, Fashion Management and large data professional/direction. Meanwhile, taking this opportunity to professional construction, training of teachers and the construction of style of study as a whole consideration, school strive to quickly occupy the Beijing city and the fashion industry talent highland, so as to establish and consolidate our position and right to speak in the future of fashion industry.

\section{RELYING ON THE "DOUBLE TRAINING PROGRAM" TO}

\section{EXPLORE THE MECHANISM OF JOINT TRAINING PERSONNEL}

For carrying out and implementing the spirit of the "double training plan", the school explores and established a joint personnel training mechanism, and formulate the detailed system and implementation scheme in the selection of students, cultivate docking program, operation and management of teaching and student feedback "Fig. 1".

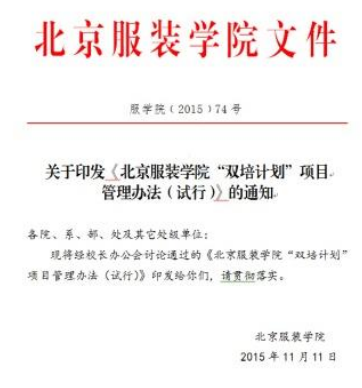

Fig. 1. Administrative measures of "double training plan"

\section{A. Establish a Scientific and Rational Selection Mechanism for Students}

In order to improve and develop the level of professional construction, while ensuring the quality of personnel training, the school carred out strict selection for the students participating in the "double training plan", and set up a scientific and reasonable selection mechanism. The first is to control the number of students. Schools ensures sending students level with the purpose of "quality is more important than number" the spirit of strict, and assures the joint personnel training quality in the same class, course and the requirements of the teaching environment with Central University students; the second is to develop selection scheme. The related departments formulate reasonable selection scheme to ensure selection of fairness according to different professional characteristics, such as the science and engineering, literature and art; the third is the defense committee was established. After the sort of professional ranking or evaluation organizations, the relevant departments organize students to participate in the respondent who are voluntary enrollment and meet the conditions, and each set up a defense committee to guarantee the selection of justice; the fourth is to open the selection process each link. Each link such as the registration, sorting, selection, defense, publicity is open and other final results are needed to inform, to ensure public selection.

\section{B. Establish Training Program Docking Mechanism}

In order to ensure the personnel training system, scientific and reasonable, school organize the related departments to established "virtual Department" including both teachers from the Central University and the Beijing municipal colleges and universities, they carefully study the cooperation of college training program to realize the successful docking "Fig. 2". The first is a tailored training program. The teachers of "Virtual Department" should carry out the training program from two schools, both discuss for joint training students develop viable solutions; the second is to determine the guidance of teachers. The relevant profession determine the professional teachers for the students to instruct selection of course in order to train the program to implement; the third is to ensure that personnel training. In the training program with both sides of the high quality curriculum, they ensure personnel training advantages; the forth is a clear implementation plan. They study in various aspects of teaching mode, teaching content, practice and implementation way to ensure the smooth implementation of the program.

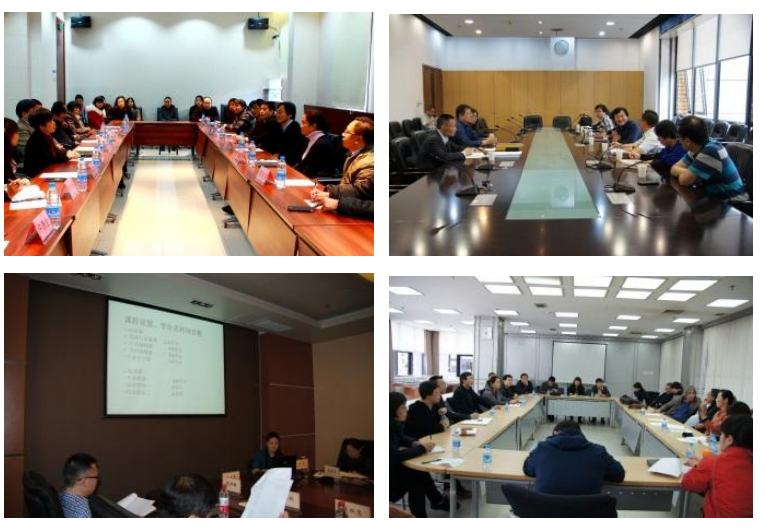

Fig. 2. Discuss the personnel training system

\section{Establish a Matching Teaching Operation Management Mechanism}

The effect of talent training needs the orderly operation of each link to ensure the teaching quality. In order to ensure the teaching quality of the joint training, we set up the teaching operation management mechanism "Fig. 3". The first is the establishment of three level management systems about teaching operation. The specially person assigned by dean's office communicate and coordinate something about teaching operation, student achievement, student management and so on, the person designated by secondary colleges of sending students is in charge of coordination about professional, teaching team, and the implementation of curriculum; the second is determining in the management of students' status. The school is management unit of sending students' school roll and the Central University has to establish temporary school 
roll in order to manage something of sending students' for education, teaching, educational administration and temporary school management. The sending students should register each semester in accordance with the requirements of the Central University; the third is to set up the identification system of the achievements and the credit. Cooperation provides transcripts and corresponding credits of the course of repair to our school in each semester (year) and awards realistic qualifications for students. Recognition of achievements and credits should be done by the school, it is inputted into management system. The forth is to complete the examination of graduation qualification. According to our training program, graduation qualification of sending students will be reviewed, graduation certificate and degree certificate will be awarded to grade qualified students.

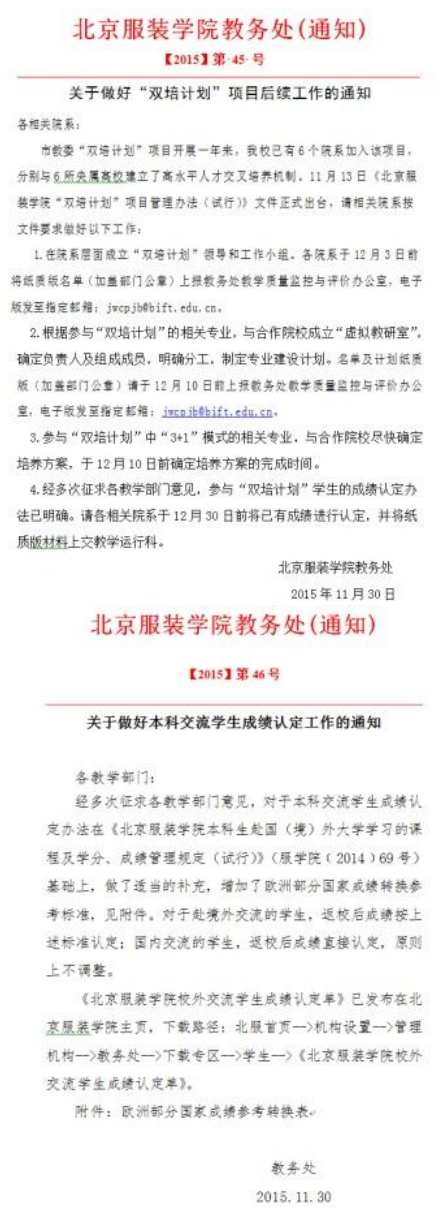

Fig. 3. Management document of teaching operation

\section{The Establishment of 4 Selected Student Learning Management and Feedback Mechanism}

The mechanism of student daily management has been established so as to grasp learning and living conditions of sending students. First, the three management system of student management should be established. Specially assigned person by Students' Affairs Division manage ideological and political work for sending students. Specially assigned person by Department of sending students regular communicate and coordinate student's work. Instructor from department of sending students manages something such as thinking, learning, and physical and mental condition. the second is the establishment of regulations to protect the rights and interests of students. Something including part-time, scholarships, honorary title selection, disciplinary treatment and so on is clear and definite on principles, procedures and methods about how to select or process, because it relates to the rights and interests of students, both sides consult settlement. The third is to establish the integration mechanism of sending students. It is coordinated about the learning and life of sending students in the Central University to successfully participate caucus activities, community activities, English "the CET examination, academic competition, innovation and entrepreneurial activity, the second classroom activities.

\section{JOINT TRAINING INITIAL SUCCESS}

Up to now, school has established cooperation with 6 Central University and one hundred and more students have been sent to study "Ttable I".

TABLE I. Situation OF SENDing Students

\begin{tabular}{|c|c|c|c|}
\hline \multirow{2}{*}{$\begin{array}{l}\text { Training } \\
\text { model }\end{array}$} & \multirow{2}{*}{ Cooperation in Universities } & \multicolumn{2}{|c|}{$\begin{array}{c}\text { Number of sending } \\
\text { students }\end{array}$} \\
\hline & & 2014 & 2015 \\
\hline \multirow{6}{*}{$2+1+1$} & Central Academy of Fine Art & 5 & 5 \\
\hline & \multirow{2}{*}{$\begin{array}{l}\text { University of International } \\
\text { Business and Economics }\end{array}$} & 12 & 12 \\
\hline & & 3 & 3 \\
\hline & Beijing University of Chemical & 5 & 6 \\
\hline & Beihang University & 4 & 8 \\
\hline & total & 29 & 34 \\
\hline \multirow{6}{*}{$3+1$} & Tsinghua University & \multirow{5}{*}{ / } & 4 \\
\hline & \multirow{2}{*}{ Central Academy of Fine Art } & & 16 \\
\hline & & & 16 \\
\hline & $\begin{array}{l}\text { University of International } \\
\text { Business and Economics }\end{array}$ & & 16 \\
\hline & $\begin{array}{c}\text { Central University of Finance and } \\
\text { Economics }\end{array}$ & & 15 \\
\hline & total & I & 67 \\
\hline
\end{tabular}

\section{A. Professional Construction}

Relying on the double training plan, The school actively carry out the construction of new professional / direction to further highlight the characteristics of running a school and improve the level of school. Based on the needs of industry in the forefront, "double training plan" of the school project involves the professional / positioning of the main direction in fashion design, information visualization design, Fashion Management and large data. It's aimed at to strengthen contact and cooperation between the relevant professional though finding combining point between design and technology with the main line of product design such as clothing, apparel, accessories and fabrics, with support of information technology such as 3D scanning, virtual reality, and human-computer interaction, with mode of marketing selling such as buyers, retail, and customized marketing selling, meanwhile, with the help of high-quality of resources Central University, the school 
carry out and perfect the construction of the new professional / direction or Urgent need of professional in Beijing.

\section{B. Faculty Construction}

It's conducive to the construction of school teachers to carry out joint training of personnel relying on "double training plan". The training mode of "double training plan" refers to the long-term follow-up project, which needs the establishment of " virtual teaching and research section " in both colleges and universities to jointly study and formulate talents training program, teaching mode, teaching requirements and implementation plan. This provides the opportunity to our school teachers with the Central University teachers to learn, communication, cooperation and participate in related research activities. This contributes to the school to improve the level of teachers, strengthen the construction of teachers.

\section{Style of Study Construction}

At present school has the visiting program with 6 Central University, such as the Tsinghua University, Central Academy of Fine Art, Beihang University, Central University of Finance and Economics, University of International Business and Economics, Beijing University of Chemical Technology and so on, they are domestic first-class colleges and universities. the students are selected and have the opportunity to participate in the "double training plan" project, especially for the third year students, competition is very fierce. The attraction from these Central University puts the construction of positive energy to students and the most students establish learning objectives at the beginning of university and consciously strengthen the learning initiative to get this rare opportunity "Fig. 4".

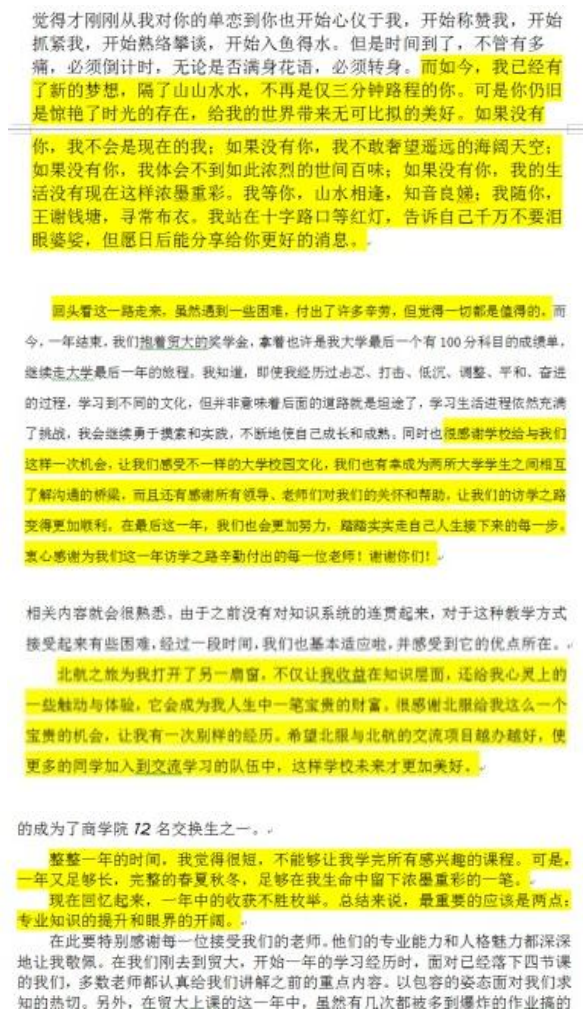

Fig. 4. Sending student's feel

\section{CONCLUSION}

In the process implementating and promoting the "double training plan", the school deeply feels that this work is an important starting point to deepen the comprehensive reform of higher education. It had a profound impact on the school of professional construction, curriculum construction, teaching staff construction and teaching resource management system with the promotion of talent training mechanism innovation.

\section{REFERENCES}

[1] Gao Yurong, Li Xiaopei, Exchange student project Promoting the internationalization of Higher Education, Journal of Inner Mongolia Normal University(Educational Science), 1st,2011,pp. 8-10

[2] Xu Juan, Establish and perfect the management system of exchange students Promote the development of exchange student project, China Electric Power Education,29th,2011 ,pp. 23-24

[3] Liu Jinjun, Wu Mengqiu. Evaluation on the training of undergraduate exchange student cooperation in the nine School Union. China University Teaching, 1st,2011, PP. 72-73.

[4] Chen dehu. Analysis of the construction of educational beliefs of college students. Heilongiiang Researches on Higher Education, 5th,2013,pp.7576. 